E18-2002-111
A. V. Gorbunov ${ }^{1}$, M. V. Frontasyeva, A. A. Kistanov ${ }^{1}$, S. M. Lyapunov ${ }^{1}$, O. I. Okina ${ }^{1}$, A. B. Ramadan ${ }^{2}$

\title{
HEAVY AND TOXIC METALS \\ IN STAPLE FOODSTUFFS AND AGRIPRODUCT FROM CONTAMINATED SOILS
}

Submitted to «Journal of Environmental Science \& Health (Toxic \& Hazardous Substance Control)»

${ }^{1}$ Geological Institute of RAS, Moscow, Russia

${ }^{2}$ National Center for Nuclear Safety and Radiation Control, Atomic Energy Authority, Cairo, Egypt 


\section{Introduction}

Assessment of human organism's intake of heavy and toxic metals from food is an important element of ecological monitoring as well as of other procedures to estimate noninfectious disease risks. If specific cases of occupational impact are left out, the main path of heavy metal intake in humans is through the digestive tract $[1,2]$.

Heavy metals enter food products as crops grow on contaminated soils or as a result of feeding animals with nutritional plants harvested in contaminated soils.

Nowadays, the number of territories that can be called ecologically clean is getting smaller and smaller. This is particularly true about areas used for agricultural purposes. Even farming areas that do not suffer from direct anthropogenic impact can hardly be considered ecologically clean if mineral fertilizers are used in them.

This also concerns irrigated cropping areas in the lower reaches of big rivers. The water of the river running through industrially developed regions gets enriched with a whole spectrum of contaminators, including heavy and toxic metals.

Another source of heavy metals in food is agricultural produce that comes from the "backyard". It is known that about $90 \%$ of potatoes and $40-70 \%$ of other vegetables in Russia are grown in the «backyard».

As a rule, it is on close-to-cities wastelands and is thus often in the zone of direct anthropogenic impact. Obviously, the products purchased by the state and sent to the market undergo sanitary inspection. This only includes, however, checks for the content of nitrates, nitrites and for general radioactivity.

To perform checks for heavy metal content is much more difficult due to analytical methods being too time-consuming. Moreover, the part of the produce consumed by the producer himself is not checked at all.

The aim of this work is the assessment of the concentration of ten heavy metals in food products obtained from three territories with principally different types of anthropogenic impact.

The first is the Astrakhan region with intense irrigated crop production where irrigation water is taken directly from the Volga.

The second is the Helwan region in the lower reaches of the Nile in Egypt where sewage from the region that houses numerous industries, including steel, metalworking, building and transport, is used for irrigation purposes.

The third is the region of strongly contaminated soils of the town of Belovo in the Kemerovo region. The town houses one of the oldest zinc plants in Russia built in 1930. Since then the plant has discharged into the atmosphere hundreds of tons of lead, zinc and cadmium that have formed powerful geochemical anomalies in the surrounding soils. They are the very soils on which most of the «backyards» of the town residents growing potatoes, vegetables and fruit are located. The irrigation is with tap or well water. 


\section{Experimental}

\section{Sampling}

Soils. Samples of soil from cropping areas were taken over an evenly distributed network with a step of $300 \mathrm{~m}$. Samples of 400-500 g each were taken from a tilth depth of up to $20 \mathrm{~cm}$ envelope-like over an area of $1 \mathrm{~m}^{2}$ averaging the material of at least 4 to 5 portions of the probes. They were then dried to the air-dry state, sifted through a $1 \mathrm{~mm}$-sieve and ground. Sampling, conservation, storage and preparation of soil and water samples for analysis were carried out in compliance with ISO/DIS $10381-1,2,3,4,5$ and national standards.

Water. Drinking water was sampled in 1.51 plastic bottles, the interior of which being previously rinsed three times with sampled water (GOST (state regulations) 24481-80 and 18963-73). To preserve the water it was acidified with dephlegmated $\mathrm{HNO}_{3}$ in the proportion $5 \mathrm{ml}$ acid/1 1 water. Sampling, conservation, storage and preparation of and water samples for analysis were carried out in compliance with ISO $5667-1,2,3$ and national standards.

Vegetation (vegetables, fruit). Sampling of vegetables and fruit was carried out simultaneously with soil sampling in the investigated area. First, soil was washed off the samples in running water and then, in distillate. After that, the samples were finely cut and dried at room temperature $\left(20-25^{\circ} \mathrm{C}\right)$ to a constant weight. Sampling, conservation, storage and preparation of and water samples for analysis were carried out in compliance national standards.

Livestock output. Sampling was performed in the household and farm sectors in the investigated region. The samples were washed with distilled water, dried at $60^{\circ} \mathrm{C}$ to a constant weight and ground. Sampling, conservation, storage and preparation of and water samples for analysis were carried out in compliance national standards.

\section{Analysis}

The samples collected in Astrakhan and Belovo (Russia) were analyzed in the laboratories of the Geological Institute, RAS in Moscow and of JINR in Dubna using neutron activation and atomic absorption analysis methods in keeping with standard procedures involving quality control with home and foreign reference samples of standard composition.

The element content in Helwan (Egypt) soil, water and foodstuffs were determined in the National Center for Nuclear safety and Radiation Control, Atomic Energy Authority, Cairo, Egypt, using AAS and XRF.

\section{Quality assurance}

Quality assurance was provided by using international standard reference materials (IAEA, Vienna; NIST, USA). 


\section{Results and discussion}

Table 1 summarizes data on heavy metal content in soils on which agricultural crops are grown in the Astrakhan region, around the town of Belovo and in the Helwan region (Egypt). The data show that soils in Astrakhan region are least enriched with heavy metals. The obtained contents are essentially lower than the RF MAC value (maximum allowable concentration) $[3,4]$ and are on the level of their background concentration. Around the town of Belovo the concentration of $\mathrm{Cr}, \mathrm{Fe}$, As is 1.5-2 times and of $\mathrm{Zn}, \mathrm{Cd}, \mathrm{Sb}, \mathrm{Hg}$ and $\mathrm{Pb}$ it is 8-10 times higher than in Astrakhan region with the concentration of $\mathrm{Zn}$ being 5 times, of As 6 time, of $\mathrm{Cd} 1.5$ times and of $\mathrm{Pb}$ almost 3 times higher than MAC.

It should be noted, however, that these elements are mainly present in the form of sulphides as plants in the region run on sulphide materials. In the Helwan region the concentration of heavy metals in soils is even higher (except of $\mathrm{Fe}$ ).

The authors do not have data on MAC values in Egypt but can say that the obtained concentration of $\mathrm{Ni}$ exceed the background concentration 2.5 times, of $\mathrm{Zn}-16$ times, of $\mathrm{Cd}-56$ times and of $\mathrm{Pb}-33$ times. It is obvious that there may be present any compounds of these metals, including oxides, sulphides, sulphates, carbonates, phosphates, etc.

Table 1. Content of heavy metals in soil, $\mu \mathrm{g} / \mathrm{g}$

\begin{tabular}{|c|c|c|c|c|c|c|c|c|c|c|}
\hline Region/element & $\mathrm{Cr}$ & $\mathrm{Fe}, \%$ & $\mathrm{Ni}$ & $\mathrm{Cu}$ & $\mathbf{Z n}$ & As & Cd & $\mathbf{S b}$ & $\mathbf{H g}$ & $\mathbf{P b}$ \\
\hline $\begin{array}{c}\text { Astrakhan } \\
\Pi=25\end{array}$ & $\begin{array}{c}70 \\
33-100 \\
\end{array}$ & $\begin{array}{c}2.52 \\
0.78-4.1 \\
\end{array}$ & $\begin{array}{c}44 \\
16-64 \\
\end{array}$ & $\begin{array}{c}21 \\
7.0-34 \\
\end{array}$ & $\begin{array}{c}74 \\
32-160 \\
\end{array}$ & $\begin{array}{c}5 \\
2.8-6.8 \\
\end{array}$ & $<0.5$ & $<0.01$ & $\begin{array}{c}0.02 \\
0.02-0.04 \\
\end{array}$ & $\begin{array}{c}11 \\
6.0-15 \\
\end{array}$ \\
\hline $\begin{array}{l}\text { Belovo } \\
\Pi=26 \\
\end{array}$ & $\begin{array}{c}93 \\
55-135 \\
\end{array}$ & $\begin{array}{c}3.44 \\
2.43-3.9 \\
\end{array}$ & n.d & n.d & $\begin{array}{c}508 \\
220-800 \\
\end{array}$ & $\begin{array}{c}12 \\
10-14 \\
\end{array}$ & $\begin{array}{c}3.9 \\
01.05 .06 \\
\end{array}$ & $\begin{array}{c}1.8 \\
0.7-4.0 \\
\end{array}$ & $\begin{array}{c}0.22 \\
0.1-0.5 \\
\end{array}$ & $\begin{array}{c}84 \\
26-260 \\
\end{array}$ \\
\hline $\begin{array}{c}\text { Egypt. Helwan } \\
\mathrm{n}=5\end{array}$ & $\begin{array}{c}190 \\
178-210 \\
\end{array}$ & $\begin{array}{c}0.63 \\
0.61-0.64 \\
\end{array}$ & $\begin{array}{c}106 \\
98-114\end{array}$ & $\begin{array}{c}377 \\
354-394 \\
\end{array}$ & $\begin{array}{c}1612 \\
1580-1646 \\
\end{array}$ & n.d & $\begin{array}{c}28 \\
25-33 \\
\end{array}$ & n.d & n.d & $\begin{array}{c}334 \\
311-357 \\
\end{array}$ \\
\hline MAC & - & - & 85 & 55 & 100 & 2 & 2 & 4.5 & 2.1 & 30 \\
\hline
\end{tabular}

Table 2 summarizes data on heavy metal content in the irrigation water for the investigated regions. The heavy metal content in the irrigation water in the Astrakhan region even satisfies quite strict regulations imposed on drinking water in Europe, USA and RF. In the town of Belovo the only element whose content exceeds the norm is Fe.

Table 2. Content of heavy metals in irrigation water, $\mu \mathrm{g} / 1$

\begin{tabular}{|c|c|c|c|c|c|c|c|c|c|c|}
\hline Region/element & $\mathbf{C r}$ & $\mathbf{F e}$ & $\mathbf{N i}$ & $\mathbf{C u}$ & $\mathbf{Z n}$ & $\mathbf{A s}$ & $\mathbf{C d}$ & $\mathbf{S b}$ & $\mathbf{H g}$ & $\mathbf{P b}$ \\
\hline Astrakhan & $<1$ & $190 \pm 70$ & $1.8+0.4$ & $3.3+0.5$ & $13 \pm 4$ & $2.5+1.5$ & $<0.2$ & $<0.1$ & $0.8+0.2$ & $<2$ \\
\hline Belovo & $<5$ & $700 \pm 100$ & $0.7+0.1$ & $2+0.5$ & $30 \pm 10$ & n.d. & $0.15+0.1$ & n.d. & n.d. & $1.1+0.2$ \\
\hline Egypt, Helwan & $300 \pm 20$ & $2850 \pm 130$ & $290 \pm 30$ & $70 \pm 10$ & $400 \pm 40$ & H.O. & $70 \pm 10$ & n.d. & n.d. & $400 \pm 30$ \\
\hline MAC RF & 100 & 300 & 100 & 1000 & 5000 & 50 & 1 & 30 & 0.5 & 30 \\
\hline MAC EU & 50 & 200 & 50 & 3000 & 5000 & 50 & 5 & 10 & 1 & 50 \\
\hline MAC USA & - & - & - & - & - & 50 & 5 & 50 & 2 & 50 \\
\hline
\end{tabular}


In the Helwan region very high concentrations of $\mathrm{Cr}, \mathrm{Fe}, \mathrm{Ni}, \mathrm{Cd}$ and $\mathrm{Pb}$ are observed in the irrigation water. This obviously explains high concentrations of these elements in the soils of the given area as soon as the irrigation has been practiced for at least 5 years.

Tables 3 and 4 present data on heavy metal content in food, vegetables and livestock nutrition plants produced in Astrakhan region (the data are recalculated per live weight).

Table 3. Heavy metal content in staple foodstuffs, Astrakhan, $\mu \mathrm{g} / \mathrm{g}$

\begin{tabular}{|l|c|c|c|c|c|c|c|c|c|c|}
\hline Object/element & $\mathbf{C r}$ & $\mathbf{F e}$ & $\mathbf{N i}$ & $\mathbf{C u}$ & $\mathbf{Z n}$ & $\mathbf{A s}$ & $\mathbf{C d}$ & $\mathbf{S b}$ & $\mathbf{H g}$ & $\mathbf{P b}$ \\
\hline white weat bread & $0.17 \pm 0.14$ & $55 \pm 38$ & $0.16 \pm 0.04$ & $1.6 \pm 0.25$ & $12 \pm 7.6$ & $<0.006$ & $0.02 \pm 0.003$ & $0.05 \pm 0.01$ & $<0.006$ & $\mathbf{0 . 2 2 \pm 0 . 1}$ \\
\hline black bread & $<0.006$ & $63 \pm 6.4$ & $0.26 \pm 0.09$ & $2 \pm 0.06$ & $15 \pm 6.1$ & $<0.006$ & $0.012 \pm 0.003$ & $0.06 \pm 0.004$ & $<0.006$ & $0.12 \pm 0.05$ \\
\hline macaroni & $\mathbf{0 . 4 2 \pm 0 . 0 6}$ & $52 \pm 17$ & $<0.09$ & $<0.006$ & $16 \pm 5.2$ & $0.02 \pm 0.007$ & $<0.006$ & $0.07 \pm 0.02$ & $<0.006$ & $<0.006$ \\
\hline meat & $0.15 \pm 0.03$ & $51 \pm 12$ & $0.07 \pm 0.02$ & $1.2 \pm 0.08$ & $68 \pm 13$ & $0.08 \pm 0.02$ & $0.019 \pm 0.02$ & $0.01 \pm 0.003$ & $0.05 \pm 0.013$ & $0.06 \pm 0.01$ \\
\hline cow kidney & $0.05 \pm 0.008$ & $65 \pm 14$ & $0.19 \pm 0.04$ & $1.72 \pm 0.33$ & $18 \pm 2.3$ & $0.04 \pm 0.008$ & $0.042 \pm 0.016$ & $0.006 \pm 0.003$ & $0.011 \pm 0.005$ & $0.29 \pm 0.09$ \\
\hline fish & $0.04 \pm 0.008$ & $9.3 \pm 1.7$ & $0.12 \pm 0.02$ & $0.92 \pm 0.29$ & $8.1 \pm 5.8$ & $0.09 \pm 0.02$ & $0.012 \pm 0.006$ & $0.036 \pm 0.007$ & $0.1 \pm 0.01$ & $0.06 \pm 0.02$ \\
\hline hen's eggs & $<0.006$ & $39 \pm 6.5$ & $0.07 \pm 0.03$ & $0.96 \pm 0.13$ & $25 \pm 4.8$ & $0.12 \pm 0.03$ & $<0.006$ & $<0.006$ & $<0.006$ & $<0.006$ \\
\hline \multicolumn{1}{|c|}{ MAC } & & & & 5 & $10-100$ & $0.1-0.3$ & $0.03-0.05$ & $0.1-0.5$ & $0.01-0.03$ & $0.3-0.5$ \\
\hline
\end{tabular}

Table 4. Heavy metal content in agriproducts, Astrakhan, $\mu \mathrm{g} / \mathrm{g}$

\begin{tabular}{|c|c|c|c|c|c|c|c|c|c|c|}
\hline Object/element & $\mathbf{C r}$ & $\mathbf{F e}$ & $\mathbf{N i}$ & $\mathbf{C u}$ & $\mathbf{Z n}$ & $\mathbf{A s}$ & $\mathbf{C d}$ & $\mathbf{S b}$ & $\mathbf{H g}$ & $\mathbf{P b}$ \\
\hline potatoes & $<0.006$ & $12.9 \pm 9.8$ & $0.09 \pm 0.06$ & $0.78 \pm 0.66$ & $5.7 \pm 2.2$ & $0.011 \pm 0.005$ & $0.011 \pm 0.004$ & $0.02 \pm 0.006$ & $<0.006$ & $0.12 \pm 0.05$ \\
\hline cabbage & $0.04 \pm 0.01$ & $14.8 \pm 2.9$ & $0.01 \pm 0.008$ & $0.54 \pm 0.45$ & $2 \pm 1.1$ & $<0.006$ & $0.004 \pm 0.001$ & $<0.006$ & $0.009 \pm 0.004$ & $0.15 \pm 0.1$ \\
\hline beet root & $0.02 \pm 0.01$ & $21 \pm 8.7$ & $0.004 \pm 0.002$ & $0.6 \pm 0.35$ & $2.6 \pm 0.9$ & $<0.006$ & $<0.006$ & $<0.006$ & $0.006 \pm 0.003$ & $0.06 \pm 0.01$ \\
\hline tomatoes & $0.02 \pm 0.01$ & $5.6 \pm 1.3$ & $0.039 \pm 0.012$ & $0.23 \pm 0.14$ & $0.7 \pm 0.5$ & $<0.006$ & $0.011 \pm 0.01$ & $0.006 \pm 0.004$ & $0.004 \pm 0.002$ & $0.03 \pm 0.018$ \\
\hline aubergine & $0.03 \pm 0.01$ & $3.7 \pm 1.5$ & $0.018 \pm 0.003$ & $0.15 \pm 0.03$ & $1.9 \pm 0.9$ & $<0.006$ & $<0.006$ & $0.004 \pm 0.001$ & $<0.006$ & $0.02 \pm 0.006$ \\
\hline pepper & $0.06 \pm 0.02$ & $11 \pm 5.8$ & $0.031 \pm 0.011$ & $0.015 \pm 0.02$ & $1 \pm 0.4$ & $<0.006$ & $<0.006$ & $<0.006$ & $0.003 \pm 0.001$ & $0.03 \pm 0.014$ \\
\hline cucumbers & $0.012 \pm 0.01$ & $7.3 \pm 3.3$ & $0.015 \pm 0.01$ & $0.26 \pm 0.11$ & $0.8 \pm 0.1$ & $<0.006$ & $<0.006$ & $<0.006$ & $<0.006$ & $0.03 \pm 0.01$ \\
\hline rice & $0.16 \pm 0.03$ & $137 \pm 14$ & $0.33 \pm 0.21$ & $3.6 \pm 0.31$ & $18 \pm 11$ & $<0.006$ & $<0.006$ & $<0.006$ & $<0.006$ & $1.58 \pm 0.75$ \\
\hline MAC & & & & 5 & 10 & 0.2 & 0.03 & 0.3 & 0.02 & 0.5 \\
\hline
\end{tabular}

Livestock nutrition plants, $\mu \mathrm{g} / \mathrm{g}$

\begin{tabular}{|c|c|c|c|c|c|c|c|c|c|c|}
\hline blades & $0.21 \pm 0.04$ & $73 \pm 22$ & $0.03 \pm 0.01$ & $1.8 \pm 0.83$ & $11.3 \pm 7.8$ & $0.037 \pm 0.01$ & $0.014 \pm 0.01$ & $<0.006$ & $0.023 \pm 0.011$ & $0.37 \pm 0.19$ \\
\hline sorog & $0.38 \pm 0.09$ & $94 \pm 22$ & $0.028 \pm 0.015$ & $1.6 \pm 0.56$ & $17 \pm 7.7$ & $<0.006$ & $<0.006$ & $0.038 \pm 0.011$ & $<0.006$ & $0.08 \pm 0.016$ \\
\hline lucenrne & $0.32 \pm 0.12$ & $55 \pm 20$ & $0.023 \pm 0.017$ & $1.2 \pm 0.53$ & $4.5 \pm 1.2$ & $<0.006$ & $<0.006$ & $<0.006$ & $<0.006$ & $0.2 \pm 0.087$ \\
\hline barley & $0.09 \pm 0.04$ & $112 \pm 25$ & $0.51 \pm 0.32$ & $3.7 \pm 1.3$ & $10.2 \pm 5.2$ & $<0.006$ & $0.027 \pm 0.016$ & $<0.006$ & $<0.006$ & $1.11 \pm 0.47$ \\
\hline
\end{tabular}

It should be noted that minerals in food are an important component of exchange processes in human organism and negative effects may arise due to sparse (insufficiency) and excessive (poisoning, microelementoses) concentration of metals in food [1,5-9]. Virtually, in Astrakhan region agriproducts and food are produced in the background conditions (judging from the data on heavy metal pollution of soils and irrigation water). This possibly explains why the content of chromium, iron, nickel, copper and zinc in staple foodstuffs is within the norm.

Figures 1 and 2 illustrate by histograms the distribution of toxicants of the first group - arsenic, cadmium, antimony, mercury and lead - in food. It should be noted that an over MAC content of arsenic is observed in hen's eggs and a high content of it is detected in meat and fish. There is also observed an over MAC content of cadmium in 
cow kidney, of mercury in fish and a high mercury content in cow kidney, a high content (though less than MAC) of lead in wheat-bread and cow kidney.

Also it should be noted that agriproduct in Astrakhan region has increased concentrations of virtually all mentioned metals in rice and the concentration of zinc and lead in it exceeds MAC. This is most probably due to the specifics of growing (application of fertilizers and sprays) or processing of rice as neither soil nor irrigation water exhibit increased concentrations of these elements. The nutrition plants produced in the region demonstrate a high concentration of zinc and mercury in blades, of zinc in sorgo and of zinc, cadmium and lead in barley.

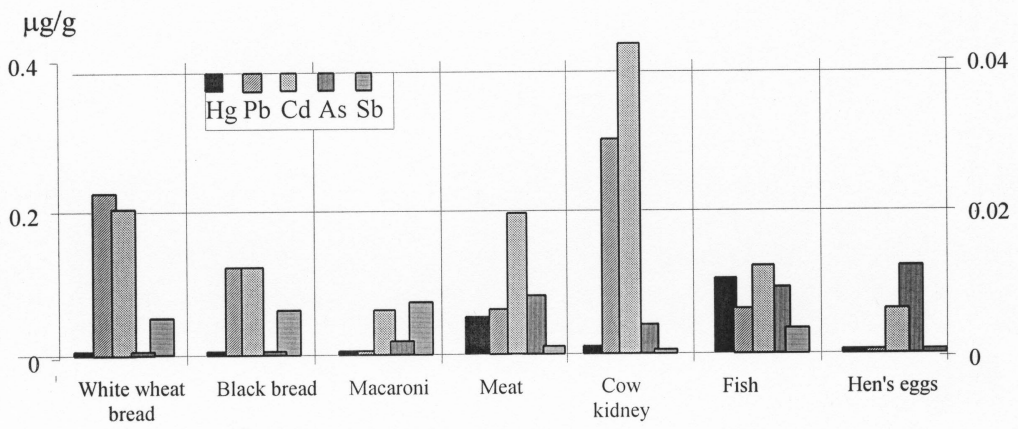

Fig. 1. The distribution of toxic metals in staple foodstuffs

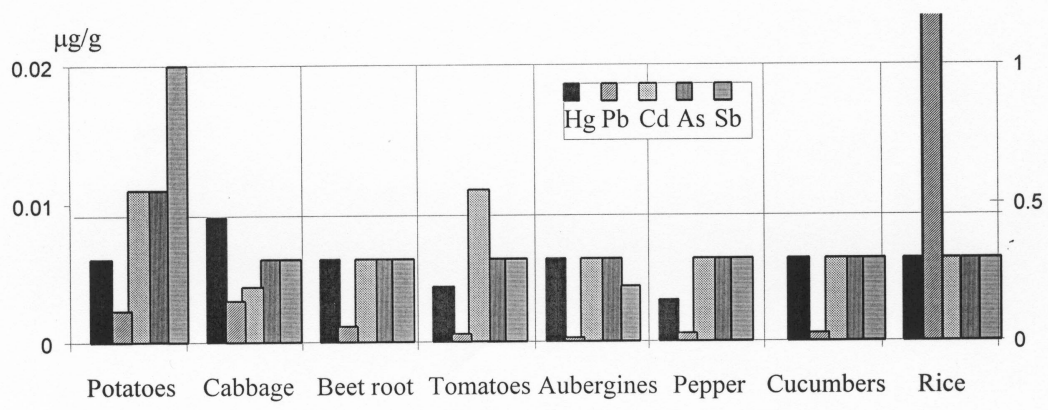

Fig. 2. The distriburtion of heavy metals in agriproducts.

Astrakhan region (the Volga delta)

Table 5 summarizes data on heavy metal content in agriproduct produced in Belovo. In the first place, sufficiently low, even compared to Astrakhankaia region's, concentrations of such elements as chromium, iron, nickel, copper, zinc and lead in all of the investigated products should be noted. Although contamination with these elements is characteristic of soils in the region, they do not enter vegetation possibly because they are mainly present in the soil as sulphides that have low mobility in soil solutions $[8,4]$. 
Table 5. Heavy metal content in agriproducts. The town of Belovo, $\mu \mathrm{g} / \mathrm{g}$

\begin{tabular}{|c|c|c|c|c|c|c|c|c|c|c|}
\hline $\begin{array}{c}\text { Object/ } \\
\text { element }\end{array}$ & $\mathbf{C r}$ & $\mathbf{F e}$ & $\mathbf{N i}$ & $\mathbf{C u}$ & $\mathbf{Z n}$ & $\mathbf{A s}$ & $\mathbf{C d}$ & $\mathbf{S b}$ & $\mathbf{H g}$ & $\mathbf{P b}$ \\
\hline Potatoe & $0.02 \pm 0.01$ & $4.1 \pm 1$ & $<0.006$ & $0.62 \pm 03$ & $3.4 \pm 0.9$ & $0.01 \pm 0.006$ & $0.1 \pm 0.07$ & $0.01 \pm 0.009$ & $<0.006$ & $0.07 \pm 0.03$ \\
\hline Cabbage & $0.02 \pm 0.007$ & $3.7 \pm 1.1$ & $<0.006$ & $0.3 \pm 0.06$ & $4.1 \pm 0.8$ & $<0.006$ & $0.01 \pm 0.008$ & $<0.006$ & $<0.006$ & $0.06 \pm 0.03$ \\
\hline Beet root & $0.04 \pm 0.04$ & $3.7 \pm 3.2$ & $<0.006$ & $1.1 \pm 0.22$ & $7.1 \pm 6.8$ & $<0.006$ & $0.06 \pm 0.054$ & $<0.006$ & $<0.006$ & $0.015 \pm 0.01$ \\
\hline Tomatoes & $0.01 \pm 0.004$ & $2.3 \pm 0.8$ & $0.05 \pm 0.02$ & $0.45 \pm 0.08$ & $1.5 \pm 0.4$ & $<0.006$ & $0.02 \pm 0.01$ & $<0.006$ & $<0.006$ & $0.084 \pm 0.008$ \\
\hline Carrot & $0.03 \pm 0.02$ & $2.5 \pm 0.5$ & $0.06 \pm 0.03$ & $0.44 \pm 0.12$ & $6.1 \pm 3.5$ & $0.01 \pm 0.002$ & $0.133 \pm 0.07$ & $<0.006$ & $<0.006$ & $0.063 \pm 0.014$ \\
\hline MAC & & & & 5 & 10 & 0.2 & 0.03 & 0.3 & 0.02 & 0.5 \\
\hline
\end{tabular}

Cadmium has a much higher mobility, which is confirmed by its high content in beet root and carrot that exceeds MAC 2 times and 4.5 times, respectively.

On the whole it may be concluded that the situation with heavy metal pollution of agriproduct in these regions of Russia is sufficiently peaceful. It is because irrigation water in these regions is sufficiently clean and heavy metals exist in the soil as lowmobility compounds.

A higher mobility of a certain metal results in its increased concentration in roots, of which bright evidence is MAC exceeding cadmium concentrations in beet root and carrot in Belovo. An even more convincing argument in favor of this conclusion is the situation in the Nile delta (Helwan region).

Table 6 summarizes data on heavy metal content in agriproduct from the Delta.

Table 6. Heavy metal content in in foodstuffs, Helwan region, Egypt, $\mu \mathrm{g} / \mathrm{g}$

\begin{tabular}{|c|c|c|c|c|c|c|c|c|c|}
\hline $\begin{array}{l}\text { Object/ } \\
\text { element }\end{array}$ & $\mathrm{Cr}$ & $\mathbf{M n}$ & $\mathbf{F e}$ & Co & $\mathbf{N i}$ & $\mathrm{Cu}$ & $\mathbf{Z n}$ & Cd & $\mathbf{P b}$ \\
\hline Bean (spot) & 0.95 & 30 & 87 & 3.2 & 6.9 & 7.4 & 52 & 0.28 & 2.2 \\
\hline Bean (white) & 0.17 & 14 & 43 & 1.2 & 1.9 & 4.5 & 29 & 0.26 & 0.9 \\
\hline Aubergines & 0.02 & 2.3 & 7.4 & 0.15 & 0.35 & 0.4 & 3.4 & 0.03 & 0.2 \\
\hline Garlic & 0.14 & 13 & 50 & 1.1 & 2.6 & 2.7 & 19 & 0.21 & 1 \\
\hline Onion & 0.22 & 18 & 70 & 1.1 & 3.1 & 3.3 & 21 & 0.27 & 1.1 \\
\hline Wheat & 1.6 & 141 & 340 & 1.7 & 10 & 14 & 170 & 1.11 & 3.2 \\
\hline Olives & 0.03 & 2.8 & 7.5 & 0.2 & 0.41 & 0.7 & 6.4 & 0.03 & 0.3 \\
\hline Cucumber & 0.011 & 4.5 & 11 & 0.23 & 0.43 & 0.5 & 5.8 & 0.06 & 0.3 \\
\hline Raddish & 0.21 & 14 & 46 & 2 & 3.8 & 4.4 & 25 & 0.28 & 2.3 \\
\hline Pepper & 0.046 & 2.8 & 13 & 0.28 & 0.7 & 0.7 & 4.7 & 0.05 & 0.4 \\
\hline Fig & 0.04 & 10 & 25 & 0.86 & 1.6 & 1.8 & 14 & 0.015 & 0.6 \\
\hline MAC & & & & & & 5 & 10 & 0.03 & 0.5 \\
\hline \multicolumn{10}{|c|}{ Lifestock nutrition plants } \\
\hline Maize (corn) & 0.24 & 8.2 & 27 & 0.71 & 1.4 & 2.8 & 19 & 0.16 & 1.4 \\
\hline Maize (leaves) & 0.4 & 16 & 45 & 2.2 & 2.8 & 3.9 & 29 & 0.48 & 1.8 \\
\hline Sorgo & 0.58 & 34 & 87 & 2.5 & 4.9 & 4.6 & 45 & 0.62 & 2.7 \\
\hline Sunflower & 0.29 & 28 & 70 & 3.1 & 6.5 & 7.5 & 54 & 0.51 & 2 \\
\hline Lucerne & 1.38 & 94 & 360 & 5.1 & 15 & 18 & 100 & 1.18 & 5.9 \\
\hline
\end{tabular}


Our attention attract very high concentrations of chromium, manganese, iron, cobalt, nickel, copper and zinc in bean, aubergine, garlic, onion, white wheat and radish. Supereminent is white wheat in which the concentration of zinc exceeds the MAC value 17 times, of copper -2.8 times, of lead -6 times and of cadmium - about 40 times. Of the first class toxicants there is present cadmium and lead whose concentrations do not exceed MAC in aubergine, olives and fig only.

A similar picture is observed for nutritional plants - high concentrations of nickel, cadmium and lead. If we take the heavy metal concentration in nutritional plants from Astrakhanskaia region as a nearly background concentration, the concentration of nickel in blades, sorgo and lucerne exceeds it 93, 175 and 650 times, of cadmium 128, 103 and 196 times and of lead 4.8, 33 and 29 times, respectively.

At the same time, it should be noted that the concentration of chromium, iron, copper and zinc in agriproduct produced in the deltas of the Volga and Nile has rather equal values - the difference is $1.5-3$ times.

\section{Conclusions}

1. The existence of high concentrations of heavy and toxic metals in food and agriproducts depends on the extent of soil contamination in the area, the quality of water used for irrigation purposes and the technology of growing and processing of a given product.

2. The concentration of heavy and toxic metals in agriproduct directly depends on the chemical form of their existence in the soil: even high concentrations of heavy metals, if present as low-mobility compounds in the soil, do not affect essentially their concentration in plants.

3. High content of some toxic metals $(\mathrm{Cd}, \mathrm{Hg}, \mathrm{Pb})$ in livestock nutrition plants may prompt the conclusion that similar high concentrations of the elements are in the livestock output such as red or white meat and eggs. It is hardly probable, however, that there exists instant dependence between them. This problem needs further investigation.

4. The irrigation of agricultural lands with sewage water of a plant or, even more, of a whole region must be done with great caution. As the experience of the Helwan region shows this kind of irrigation results in a dramatic increase of the concentration of heavy and toxic metals in end products.

The authors acknowledge that this study was carried our in the framework of INCO-COPERNICUS Project no. ICA2-CT-2000-10025. 


\section{References}

1. Moskalev Yu.I. Mineral exchange, Moskva, «Meditsina», 1985 (in Russian).

2. Stuks I.Yu. Ecological risk factors of arterial hyperpiesis, Tomsk, 1997 (in Russian).

3. Bespamiatnov G.P.; Krotov Yu.A. Maximum allowable conceentrations of chemical substances in the environment, L. Khimia, 1985, 528 p. (in Russian).

4. Alekseev Yu.V. Heavy metals in soils and plants, Leningrad, VO Agropromizdat, 1987, 56-99 (in Russian).

5. Carbonell A.A.; Aarabi M.A.; DeLaune R.D.; Gambrell R.P.; Patrick W.H.; Jr. Arsenic in wetland vegetation: Availability, uptake and effects on plant growth and nutrition. The Science of Total Environment, 1998, 217 189-199.

6. Holsbeek L.; Das H.K.; Joiris C.R. Mercury speciation and accumulation in Bangladesh freshwater and anadromous fish. The Science of Total Environment, 1997, 198, 201-210.

7. Tripathi R.M.; Raghunath R.; Krishnamoorthy T.M. Dietary intake of heavy metals in Bombay city, India. The Science of Total Environment" 1997, 208,149-159.

8. Kabata-Pendias A.; Pendias H. Trace elements in soils and plants CRS Press.Inc. Boca Raton, Florida, 1986.

9. Kovalskii V.V. Geochemical ecology. M Nauka, 1974, 298 . (in Russian).

Received on May 15, 2002. 
Горбунов А. В. и др.

Тяжелые и токсичные металлы в основных продуктах питания и сельскохозяйственной продукции, выращенной на загрязненных почвах

Приведены данные о содержании $\mathrm{Cr}, \mathrm{Fe}, \mathrm{Ni}, \mathrm{Cu}, \mathrm{Zn}, \mathrm{As}, \mathrm{Cd}, \mathrm{Sb}, \mathrm{Hg}$ и $\mathrm{Pb}$ в основных продуктах питания и сельскохозяйственной продукции, выращенной в России (Астраханская обл. и г. Белово) и Египте (район Хелуана). Показана зависимость концентрации тяжелых металлов в сельскохозяйственной продукции от содержания и формы их нахождения в поливных водах и почвах.

Работа выполнена в Лаборатории нейтронной физики им. И. М. Франка ОИЯИ, Геологическом институте РАН (Москва) и в Национальном центре по ядерной безопасности и радиационному контролю Комиссии по атомной энергии (Каир, Египет).

Gorbunov A. V. et al.

E18-2002-111

Heavy and Toxic Metals in Staple Foodstuffs and Agriproduct

from Contaminated Soils

This article presents basic data on the content of $\mathrm{Cr}, \mathrm{Fe}, \mathrm{Ni}, \mathrm{Cu}, \mathrm{Zn}, \mathrm{As}, \mathrm{Cd}$, $\mathrm{Sb}, \mathrm{Hg}$, and $\mathrm{Pb}$ in staple foodstuffs and agriproduct grown in Russia (Astrakhan region and the town of Belovo) and Egypt (Helwan region). The dependence of the concentration of metals in agriproducts on the content and chemical form of existence in irrigation water and soils is indicated.

The investigation has been performed at the Frank Laboratory of Neutron Physics, JINR, Geological Institute of RAS (Moscow, Russia) and at the National Center for Nuclear Safety and Radiation Control, Atomic Energy Authority (Cairo, Egypt). 
Макет T. E. Попеко

ЛР № 020579 от 23.06.97.

Подписано в печать 22.07.2002.

Формат $60 \times 90 / 16$. Бумага офсетная. Печать офсетная.

Усл. печ. л. 0,68. Уч.-изд. л. 1,31. Тираж 295 экз. Заказ № 53433.

Издательский отдел Объединенного института ядерных исследований

141980 , г. Дубна, Московская обл., ул. Жолио-Кюри, 6. 